\title{
Globalization and Formal Sector Migration in Brazil
}

\author{
ERNESTO AGUAYO-TÉLLEZ \\ CIE, Universidad Autónoma de Nuevo León, México \\ MARC-ANDREAS MUENDLER \\ University of California, San Diego, CESifo, and NBER, USA \\ and \\ JENNIFER P. POOLE* \\ University of California, Santa Cruz, USA
}

\begin{abstract}
Summary. - Comprehensive linked employer-employee data allow us to study the relationship between domestic formal sector migration in Brazil and globalization. Considerable worker flows in the formal labor market during 1997-2001 are directed toward lower income regions - the reverse flows of those often posited for informal labor markets. Estimation of the worker's multi-choice migration problem shows that previously unobserved employer covariates are significant predictors associated with migration flows. These results support the idea that globalization acts on internal migration through job stability at exporting establishments and employment opportunities at locations with a concentration of foreign owned establishments. A $1 \%$ increase in exporter employment predicts a $0.3 \%$ reduced probability of migration. A $1 \%$ increase in the concentration of foreign owned establishments at potential destinations is associated with a $0.2 \%$ increase in the migration rate.

(C) 2010 Elsevier Ltd. All rights reserved.
\end{abstract}

Key words - trade and labor market interactions, domestic and regional migration, multinational firms

\section{INTRODUCTION}

When economies adjust to globalization, local resources shift. Workers change jobs and internal migration flows ensue, depending on the degree of individual mobility. We study the association between international economic integration and domestic migration using linked employer-employee data that comprehensively trace individual workers and their employers over time in Brazil, a major developing country. Brazil underwent salient efforts to integrate its economy globally, and simultaneously experienced accelerating domestic migration. Formal sector migration reallocates resources across regions and activities and is thus an important source of a country's gains from specialization after market oriented reforms.

Brazil has long exhibited high rates of internal migration, similar to many developing countries. Over the past century, massive flows of internal migrants left states in the North and Northeast for the growing urban centers in the Southeast, and for Brasília. Migration has not subsided. To the contrary, estimates of lifetime interstate migration rates grew from $20 \%$ of the population in 1980 (Martine, 1990, chap. 2) to $40 \%$ of the population in 1999 (Fiess \& Verner, 2003). This migration surge coincides with market oriented reforms, a shift in development strategy towards regional policies that foster local economic strengths, and Brazil's progressing integration into the global economy since the late 1980s. Brazil implemented major trade reforms in the early 1990s, trade integration with its Southern Cone neighbors in 1993, gradual Foreign Direct Investment (FDI) liberalizations over the 1990s, and an exchange rate devaluation in 1999 that facilitated foreign market access for exporters. The total stock of FDI in Brazil, for instance, stood at US\$ 115.5 billion in 1995. Within five years, this stock more than quintupled following Brazil's trade and capital account liberalizations and macroeconomic stabilization. Most foreign investments flowed to newly privatized utilities and services companies, impacting industries beyond manufacturing.

We document recent migration patterns across states in Brazil using comprehensive and, in their scope, internationally unprecedented linked employer-employee data for a developing country. The data show that one third of the job changing workers in Brazil's formal sector migrate across state borders to find new formal employment every year in the 1990s. Contrary to long term evidence from household cross-sections, we show that recent annual migration flows of formal sector workers are directed towards uncommon destinations. Select states in the Center-West, North and Northeast receive large flows of formal sector immigrants. This stands in contrast to the assertion that the typical migrant flow in Brazil runs from the low income North to higher income South.

Our data link workers to their employers across all sectors of the economy. The data are uniquely suited to investigate how globalization related employer characteristics are associated with migration flows. While most Brazilian formal

\footnotetext{
* We thank participants of the UNU-WIDER Project Conference on The Impact of Globalization on the Poor in Latin America as well as Juliano Assunção, Eli Berman, Gordon Hanson, Craig McIntosh, Jim Rauch and two anonymous referees for valuable comments. Our special thanks to Paulo Furtado de Castro for help with the RAIS and SECEX data and to Patrícia Vanderlei Fernandes and Paulo Marcelo Cavalcanti Muniz of the BCB for help with the RDE-IED data. Lisa-Anne Chung and Shenje Hshieh provided valuable research assistance. Muendler acknowledges NSF support (SES-0550699) with gratitude. Final revision accepted: January 23, 2009.
} 
workers move between national and non-exporting establishments, there are notable differences between migrants and stayers in their exposure to multinational and exporting establishments. The average migrant in the sample is more likely to move to a job at a foreign owned or exporting establishment than a non-migrant. Job changers to foreign owned establishments benefit from a considerably steeper tenure wage profile than workers at domestic owned establishments.

We analyze these sample characteristics using the Dahl (2002) methodology to account for the multiplicity of destination choices that a migrant faces, while also controlling for withinstate job changes. Our estimates for the period during 19972001 provide additional support for the idea that globalization acts on internal migration through the growth of employment opportunities at locations with a high concentration of foreign owned establishments and the stability of employment at exporting establishments. A $1 \%$ increase in exporter employment predicts a $0.3 \%$ reduced probability of migration, and a $1 \%$ increase in the concentration of foreign owned establishments at potential destinations is associated with a $0.2 \%$ increase in the migration rate. The importance of foreign owned establishments in the immigration region, beyond the spot wage, is consistent with the economic rationale that migrants can expect benefits beyond the spot wage difference, such as steeper wage paths at foreign owned establishments or more favorable overall labor market conditions. Our estimates do not necessarily reflect causal relationships, however. The objective of this paper is to document previously unobserved formal sector migration flows, and to relate migration decisions in the formal sector to previously unobserved employer characteristics.

Our findings on formal sector migration flows have conceivable implications for poverty alleviation and income inequality. In the past, import substituting policies reinforced the geographic clustering of Brazil's industry and contributed to income concentration in the South and Southeast regions. With trade liberalization in the 1990s and the expansion of infrastructure investments and export promotion programs in the North, Northeast, and Center-West, production has dispersed and regional income inequality has dropped. Meanwhile, interstate worker mobility accelerated. Most notably, a considerable fraction of formal sector workers moved toward lower income regions during 1997-2001. This is the reverse of the flow often posited for informal labor markets in the flavor of the traditional Harris and Todaro (1970) migration framework. ${ }^{1}$ Our formal sector labor market data show that moderately and highly skilled workers could expect wage premia in emerging regions within Brazil during 1997-2001. While the exact effects of resulting worker flows on the immigration region are beyond the realm of this paper, relatively skilled migrants who fill vacant positions arguably complement the local labor force in otherwise unfilled occupations and facilitate the attraction of new industries, which conceivably contribute to job creation and perhaps a reduction of urban unemployment. ${ }^{2}$
The remainder of this paper is organized as follows. In the next section, we summarize the literature on internal migration and discuss recent policy reforms in Brazil. Section 3 describes the data, while Section 4 offers descriptive statistics relating globalization to cross-state migration in Brazil. Section 5 offers multivariate support for the descriptive evidence. We introduce the statistical model of the migration decision, paying special attention to the self-selection of migrants and simultaneous within-state job changes, and present estimation results alongside. We conclude with some final remarks.

\section{INTERNAL MIGRATION AND POLICY REFORMS}

Considerable economic disparities persist between Brazil's five regions. As Table 1 shows, per capita GDP in the Southern regions (South and Southeast) is more than triple the per capita GDP level in the Northern regions (North and Northeast). ${ }^{3}$ Even within regions, incomes between Brazil's 27 states differ. These regional disparities offer incentives for migration. Brazil's population in 2001 was approximately 176 million, with around half ( 85 million) actively participating in the labor force. The International Labor Organization estimates that $66 \%$ of the labor force held a formal sector job in 1997 (Meier $\&$ Rauch, 2005). Our data cover the formal sector.

\section{(a) Internal migration}

Historically, migrants in Brazil moved to cities where import substituting industries flourished and away from the rural interior that underwent agricultural modernization (Martine, 1990, chap. 2). Declining agricultural prices contributed to rural displacement, and migration to the coastal cities accompanied Brazil's industrialization process and urban growth (Yap, 1976; Graham, 1970). The combination of rising wages in the industrial South and declining wages in the rural North accelerated the flight from rural areas over the decades. Using data from Brazil's decennial censuses, Martine (1990, chap. 2) reports that the number of Brazilians residing in a state other than the state of birth was 3.5 million in 1940 (or $9 \%$ of the population). This share increases steadily until 1980, when close to $20 \%$ of the population reside outside their state of birth. ${ }^{4}$ Migration accelerates further during the last two decades of the 20th century and results in a doubling of the migrant population share (with the primary residence outside the birth-state) to $40 \%$ by 1999 (Fiess \& Verner, 2003).

Research into the determinants of internal migration can be classified into two broad categories: research that concentrates on migrant characteristics, and research that concentrates on regional characteristics as primary determinants. Early studies on Brazil, such as Sahota (1968), Graham (1970), and Yap (1976), relate internal migration to regional and sectoral wage and income differences. In a recent study, Fiess and Verner (2003) place primary attention on migrant and stayer charac-

Table 1. Regional characteristics, 1997-2001.

\begin{tabular}{lccccc}
\hline & GDP per capita & Population (millions) & \multicolumn{3}{c}{ Share of value added in } \\
\cline { 4 - 6 } & & & Agric. & Manufact. & Services \\
\hline North & 2,667 & 1.9 & 0.106 & 0.260 & 0.634 \\
Northeast & 2,111 & 5.4 & 0.094 & 0.345 & 0.561 \\
Southeast & 7,507 & 18.3 & 0.054 & 0.416 & 0.529 \\
South & 6,762 & 8.5 & 0.139 & 0.428 & 0.433 \\
Center-West & 7,464 & 3.0 & 0.188 & 0.206 & 0.031 \\
Average & 4,364 & 6.4 & 0.110 & 0.322 & 0.130 \\
\hline
\end{tabular}

Source: IBGE (1997-2001). 
teristics. The authors find that migrants from the Northeast to the Southeast face strong economic incentives for migration, while migrants from the Southeast region to the Northeast region are faced with lower estimated returns to migration, suggesting that non-pecuniary factors may play a relatively larger role for South-to-North migration.

Without detailed information on employer and state level exposure to international markets, prior research largely neglects the role of market oriented reforms and globalization for internal migration. This paper aims to shed light on the relationship between formal sector migration and economic reform, as promoted through Brazil's trade, investment, and macroeconomic policy shifts. We will control for wage differentials and self-selection of migrants, using a $1 \%$ random sample of the national formal workforce, and identify workers' annual state-to-state migrations during 1997-2001. While much previous work identifies single migration decisions from a cross-section of workers, drawing on decennial censuses or household surveys, the depth of our linked employer-employee data set allows us to identify worker mobility at the annual horizon and to incorporate employer level information on exposure to global markets. Contrary to worker cross-sections, where worker characteristics are typically only measured at a single time after migration, we can draw on worker, employer, and location information before and after the migration decision. Lacking information on informal workers, however, our results can only represent migration flows within the formal sector.

Prior research shows that chief among the migration determinants are migrant characteristics such as age, sex, and educational attainment, as well as regional characteristics like per capita income differentials and urbanization rates. Beyond those covariates, we include factors related to globalization at the migrant level-employment in a multinational enterprise and employment in an exporting establishment-and control for state level information on the share of foreign owned and exporting establishments as factors in the migration decision.

\section{(b) Policy reforms}

Brazil offers a particularly interesting setting to study the association between globalization and domestic formal sector migration because salient policy reforms occurred with marked time variation and differential regional responses. After Brazil's democratic transition, it was macroeconomic stabilization and pro-competitive reform, including large scale trade liberalization and the privatization of utilities, that dominated the national economic policy agenda of the 1990s. Figure 1 illustrates the considerable growth in FDI inflows and exports as a percentage of GDP for the Brazilian economy during 1995-2001. These notable increases followed macroeconomic stabilization and trade liberalization policies, which helped bring down inflation rates and opened the Brazilian market to international competition.

Average ad valorem tariff rates fell from $41 \%$ to $18 \%$ during 1988-89. In the early 1990s, Brazil abolished the remaining non-tariff barriers inherited from the import substitution industrialization era (Bittencourt, Larson, \& Kraybill, 2008), brought nominal tariffs further down to below $15 \%$, and formed the free trade area Mercosul with its Southern Cone neighbors (Argentina, Paraguay, and Uruguay). Brazil's entry into Mercosul in 1991 contributed to attracting inflows of FDI to the country as a regional export base for multinational firms. In addition, gradual FDI liberalizations and the privatization of state owned companies over the 1990s contributed to attracting capital inflows. After decades of high inflation and several unsuccessful stabilization attempts, the Brazilian government succeeded with its macroeconomic stabilization plan (Plano Real) in 1994 and lastingly ended hyperinflation. These reforms put Brazil's economy on a pro-competitive basis and precede our sample period. It is mainly during the second half of the 1990s that the Brazilian economy exhibits heightened capital inflows and export activity. We hypothesize that Brazil's progressing integration into the global economy is related to domestic factor reallocations, which arguably, in turn, affect formal sector migration flows.

Perhaps not surprisingly in a context where macroeconomic stabilization and pro-competitive reform dominated the national economic agenda, development policy was increasingly left to states and municipalities. In fact, even the federal multiyear development plan (Plano Plurianual) for the years 199699 emphasized the importance of regional clusters of integration and development and proposed a location specific economic policy agenda to address regional and social inequalities by targeting existing local economic strengths. Recent theoretical advances in regional economics, with an emphasis on dynamic agglomeration effects, provided the theoretic rationale for the policy shift towards a regional focus (Amaral-Filho, 2001). The government of Ceará (CE) state is a striking example of the change in development policy. Ceará designed fiscal incentives for the relocation of industries
FDI inflows as a percentage of GDP

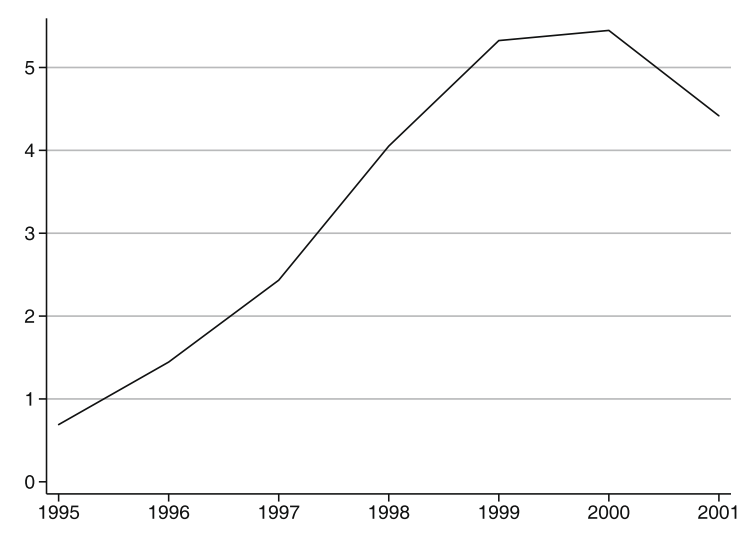

Exports as a percentage of GDP

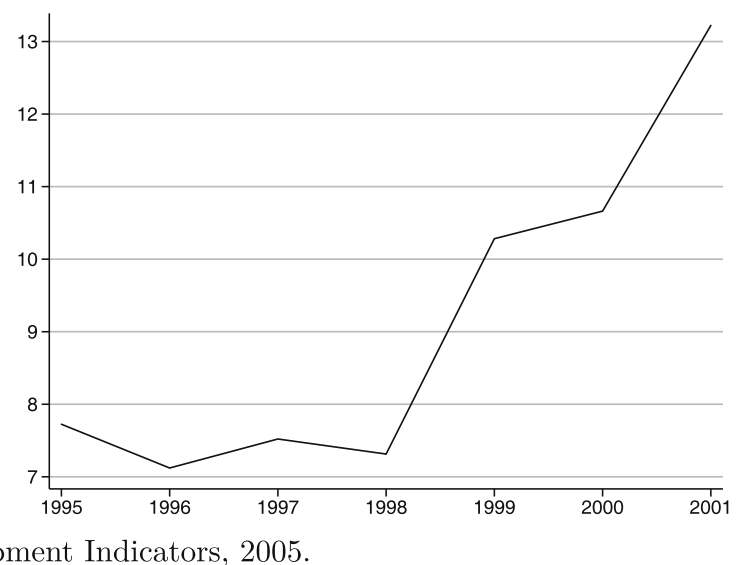

Figure 1. FDI inflows and exports, 1995-2001. 
in order to shift economic activity from agriculture and low skill intensive services to manufacturing and high value added services within the state, and to attract companies from other states (Amaral-Filho, 2003, chap. 16).

More generally, these political efforts and the public interest in regional development promoted the relocation of industries towards previously less favored regions in Brazil's North, Northeast and Center-West. The regional policies were geared to attract firms to so-called arranjos produtivos locais (Lastres, Cassiolato, \& Campos, 2006, chap. 1), or local production and innovation clusters that benefitted from agglomeration effects. ${ }^{6}$ While the local policies were largely targeted at fostering small and medium sized companies, the relocation of national firms' establishments from one region to another also played a role in local development strategies. In some cases, export promotion was an explicit element in the development programme for a cluster. Even though multinational enterprises were not a specific target, infrastructure investments and the benefits of agglomeration effects naturally tended to attract foreign companies alongside.

Using information on foreign ownership and the exporting status of local establishments, this paper will relate migration decisions to employer and state level characteristics associated with globalization. While we will control for additional and potentially confounding employer and state effects with a rich set of covariates and fixed effects, our identification strategy does not aim to pinpoint the exact local conditions and policies that initially attracted foreign owned and exporting establishments to the potential migration destinations.

\section{DATA}

Our main data source comes from Brazil's administrative records of formal sector workers and their employers. We combine this worker information with complementary data sources on foreign and exporting establishments, industry level exposure to globalization, and state level characteristics.

\section{(a) Worker data}

The linked employer-employee data are from the Brazilian Labor Ministry (Ministério do Trabalho e Emprego). By law, all registered establishments are required to report to the ministry on their workers every year. In practice, only formally employed workers will be properly reported. This information has been collected in the administrative records Relação Anual de Informações Sociais (RAIS) since 1986. For most of our analysis, we use information from RAIS for the years 19972001 when we also have complementary information. RAIS includes a unique and time invariant worker identification number PIS (Programa de Integração) for the private sector, which coincides with the PASEP (Programa de Formação do Patrimônio do Servidor Público) ID when a worker transitions into the public sector. Also included in the data are the tax number of the worker's establishment (Cadastro Nacional de Pessoa Jurídica, CNPJ), the industrial classification of the worker's establishment (Classificação Nacional de Atividades Economicas, CNAE) and the state of the worker's establishment. ${ }^{7}$ RAIS covers establishments in any sector of the economy, so workers in the services and utilities industries, to which much of the foreign investments flowed in the second half of the 1990s, are included.

The main benefit of the RAIS database is the ability to trace individually identifiable workers over time, across establishments, and across states. Brazilian establishment tax numbers are common across many databases so that the information from RAIS can be linked to complementary establishment level data sources. The RAIS worker data offer worker information on gender, age, educational attainment, ${ }^{8}$ and the worker's tenure at the establishment in months, as well as job information including the annual real wage in reais, the occupational classification (Classificação Brasileira de Ocupações, $\mathrm{CBO}$ ), and the type of job separation when recorded.

We draw a $1 \%$ random sample of the national data and restrict observations as follows. First, only workers with correct 11-digit worker identification numbers are included. ${ }^{9}$ Following Abowd, Kramarz, and Margolis (1999), we restrict the set of workers to only those workers receiving positive wages. Finally, for workers with multiple jobs in a given year, only the most recent job is included in the sample. If a worker has multiple current jobs, the highest paying job is included in the sample. This restriction rests on the assumption that workers rely on the last and highest paying job of the year in their decision to migrate.

\section{(b) Complementary establishment, industry, and state data}

By law, all foreign investments are registered with Brazil's central bank (Banco Central do Brasil (BCB)) in its Registro Declaratório Eletrônico-Investimentos Externos Diretos (RDE-IED). These establishment level data are not publicly available, but the BCB made available portions of the RDE-IED for the years 1996-2001 ${ }^{10}$ for our research, including information on both flows and stocks of foreign investment. Our data include: first, a list of all establishments (CNPJ tax numbers) with a positive inflow of FDI for the years 1996-2001; and second, a list of all establishments (CNPJ tax numbers) with a positive stock of foreign capital in the year 2001. Although we lack direct information on an establishment's FDI stock by year, these data allow for a procedure to infer with considerable confidence which establishments are at least partially foreign owned in a given year during 1996-2001.

We define an establishment to be at least partly foreign owned in year $t$ if the establishment received an inflow of foreign capital in year $t$. We note that establishments receiving inflows of foreign capital in year $t$ may maintain a stock of foreign capital in later years. Therefore, establishments with a positive stock of foreign capital in 2001 are classified as foreign owned in all years $\tau \geqslant t$ after the initially observed inflow at year $t$, even if no inflow is observed in the intervening years. If we observe no FDI inflow to an establishment but an FDI stock in 2001, we consider the establishment foreign owned for the entire sample period. Conversely, if we observe no foreign ownership by 2001, we assign the year with the last FDI inflow as the final year of foreign ownership. ${ }^{11}$ Our main concern are establishments without any recorded inflows of foreign investment and no stock of foreign capital in 2001. By our definition, these are considered domestically owned enterprises. So, we may miss foreign owned establishments if there was an initial inflow of foreign capital before our sample period and a full divestiture at some point during the sample period. Note, however, that retained earnings are inflows under common FDI definitions so that inflows are likely to be observed in every year of foreign ownership. Nevertheless, missing some (partly) foreign owned establishments moves the odds of detecting a statistically significant effect of foreign ownership against us and potentially weakens our later results.

We consider partial foreign ownership of a holding company to affect all establishments of the corporate group. Using $\mathrm{BCB}$ information on the corporate ownership relations among 
Brazilian firms, we count an establishment as at least partly foreign owned in year $t$ if it is a subsidiary of a foreign owned enterprise. Matching the RDE-IED information to the RAIS data at the establishment level, we define an indicator variable equal to one if a worker holds a job at a foreign owned establishment. We also compute the share of foreign owned establishments at the state level.

We use exporter status data from the Brazilian customs office Secretaria de Comércio Exterior (SECEX). SECEX records all legally registered establishments in Brazil with at least one export transaction in a given year. This is our definition of an exporting establishment. We match the SECEX information from 1997 to 2001 to our RDE-IED and RAIS data and define an indicator variable equal to one if a worker holds a job at an establishment with a positive dollar value of free-on-board exports in a given year. We also compute the share of exporting establishments at the state level. ${ }^{12}$

Figure 2 shows average shares of foreign owned establishments and of exporting establishments by state during 19972001, with darker shades reflecting higher shares. Amazonas (AM), in the North, has the highest share of foreign investments, as defined by the share of foreign owned establishments in the state during the five year period from 1997 to 2001. This reflects Brazil's export promotion programs for the Amazon and export processing zones around the capital city Manaus. São Paulo (SP) and Rio de Janeiro (RJ) states rank second and third, respectively. The Northeastern states of Tocantins (TO), Sergipe (SE), and Acre (AC) are the locations with the smallest shares of foreign ownership. Amazonas state also ranks the highest in terms of exporting establishments to total establishments. Pará (PA) state, also in the North, has the second highest share of exporting establishments. Otherwise, exporting establishments are largely concentrated in the Southern regions.

In order to reflect a Brazilian industry's lagged exposure to global competition, we obtain export and import information from the World Trade Flow (WTF) database (Feenstra, Lipsey, Deng, Ma, \& Mo, 2005) for the years 1996-2000. We extract sector level trade flow statistics by $\operatorname{SITC}$ (Rev. 2) 4-digit product category in current US\$ for Brazil's exports and imports, and map the trade flow information to the 2-digit $C N A E$ sector level in RAIS (broadly comparable to the SITC 2-digit level). We then use a state's industrial composition from RAIS to calculate last period's location specific exposure to foreign trade.
We obtain state level information on population, GDP per capita, urbanization rates, and value added in agriculture, manufacturing, and services from the Brazilian Census Bureau Instituto Brasileiro de Geografia e Estatística (IBGE; see Table 1). These variables are traditionally reported among the key determinants of the migration decision.

\section{DESCRIPTIVE STATISTICS}

The complete linked employer-employee database includes the full employment history of formal sector workers in Brazil from 1997 to 2001 .

\section{(a) Migrant and stayer characteristics}

We define workers as migrants if the state of the worker's establishment at time $t$ is different from the state of the worker's establishment at time $t+1$. Conversely, if a worker remains in the same state for years $t$ and $t+1$, he is considered a stayer, but may change jobs, that is switch employers, within the same state.

The final 1\% random sample includes 480,729 workers in 339,515 establishments over the period 1997-2001 (for $1,548,131$ total observations). We use the 366,206 individuals (approximately three-quarters of the formal sector labor force) who appear in the data for at least two consecutive time periods to calculate annual migration statistics. ${ }^{13}$ Workers who cannot be traced over time include workers who die or retire and workers who exit the formal sector to informal employment, to self-employment or to unemployment, and workers who choose to leave the labor force. ${ }^{14}$ While our data on formal sector workers may miss these transitions into the informal sector and unemployment, using cross-sectional household surveys to study migration patterns has its own shortcomings. Household data potentially exaggerate unemployment rates because formal sector migrants are classified as missing and removed from both the numerator and denominator of the unemployment rate. Our paper documents formal sector migration by tracing individual workers over time and across states, and as such, this paper complements current migration studies using household surveys.

The workers are from any of the 27 Brazilian states and any sector of the economy. Migrants represent around $2 \%$ of the
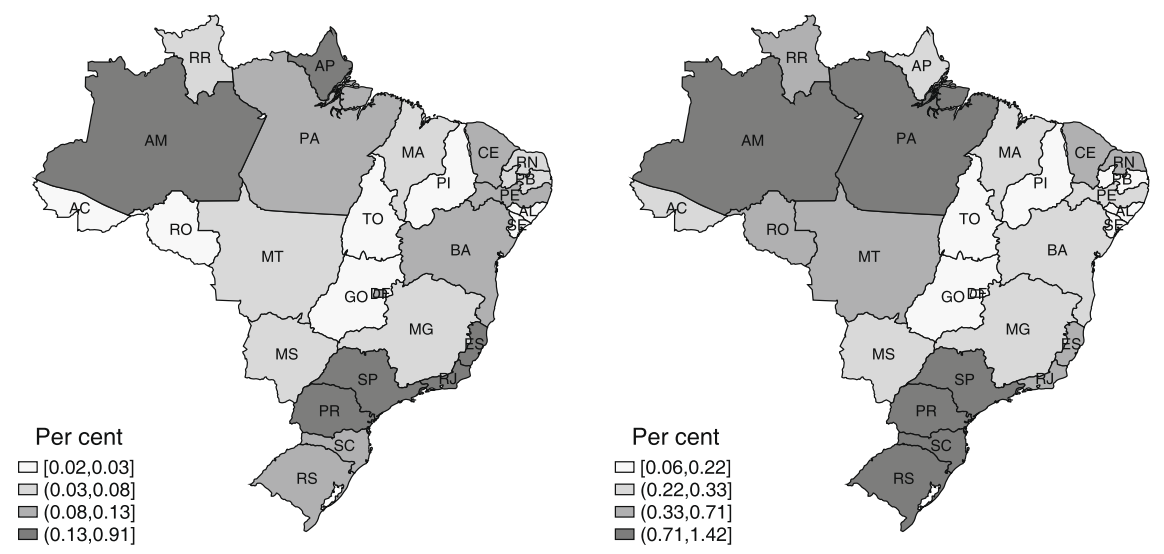

Sources: RDE-IED and SECEX, 1997-2001.

Figure 2. Global integration of Brazilian states, 1997-2001. 
Domestic v. foreign

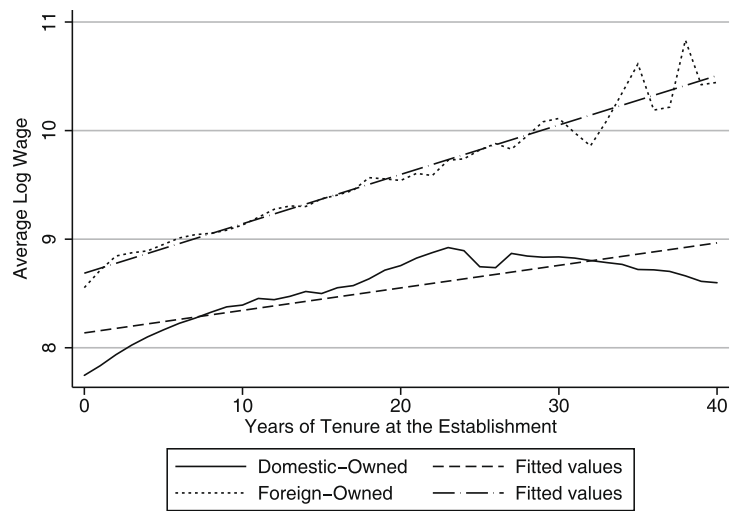

Non-exporting v. exporting

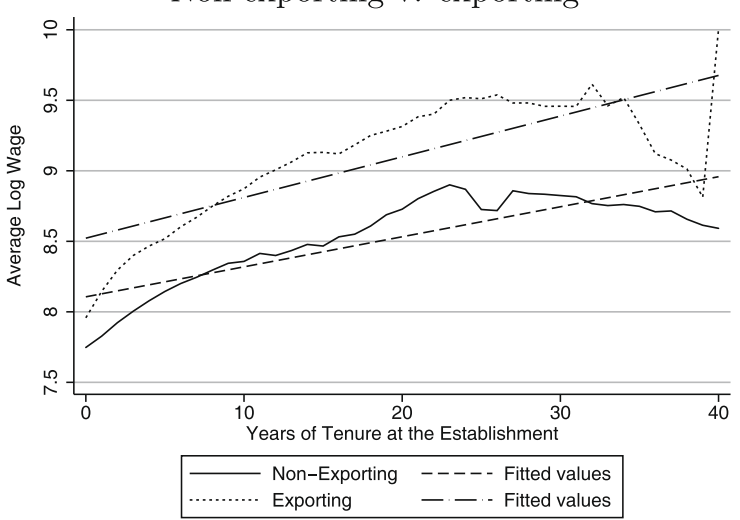

Sources: RAIS (1\% random sample), RDE-IED, and SECEX, 1997-2001.

Figure 3. Tenure wage profiles, by establishment type, 1997-2001.

complete sample (22,837 observations). An additional benefit of our longitudinal data over traditional household surveys is the ability to trace workers with multiple migration episodes. Of the 17,568 migrants in the sample, approximately one-quarter are repeat migrants. Our data contain 3,996 workers with two migration episodes, 530 workers with three migration episodes, and 65 workers with four migration episodes. ${ }^{15}$

Formal sector migrants are most often from the CenterWest and Northern regions, where $3.9 \%$ and $3.0 \%$ of workers are migrants, respectively, while workers from the Southeastern region are least likely to move between states $(2.0 \%$ of workers migrate). As a consequence of annual migration rates around $2 \%$ on average, small differences in employment patterns may have a potentially strong impact on migration patterns.

Small annual migration rates can nevertheless be associated with considerable migration backgrounds in a cross-section of households and workers. Suppose a worker's migration odds are independent of past migration and that a worker migrates with equal probability in any year during his 40 years of labor force experience. Then an annual migration rate of $2 \%$ among formal sector workers will result in a share of 55\% of workers with a migration background among the cohort just before retirement $\left(1-.98^{40}\right)$, and a $33 \%$ migration background for a worker half-way through the active time in the labor force $\left(1-.98^{20}\right)$. Little is known about the odds of repeat migration, and little is known about annual migration rates among workers outside the formal sector. Yet the notable share of Brazil's population with a cross-state migration background-around $40 \%$ by the late 1990s (Fiess \& Verner, 2003) - suggests that the annual formal sector migration rate of around $2 \%$ is perhaps similar to overall migration rates.

Table 2 contrasts average worker characteristics of migrants and stayers during 1997-2001. Though migrants and stayers in our formal sector sample are remarkably similar, there are a few key differences. Formal sector migrants are less likely to have a high school degree and more likely to have only a primary school education than stayers. Meanwhile, migrants are equally likely to have at least some college education as non-migrants. This highlights an important difference between our data on formal sector migration and conventional statistics on rural-to-urban migration in developing countries. Formal sector migration is relatively higher skilled migration. Over $6 \%$ of formal sector workers with at least some college education migrate across state lines at least once during the sample period. In contrast, just $2.4 \%$ of formal sector workers with a high school degree migrated during the five year period

Table 2. Average worker characteristics, 1997-2001.

\begin{tabular}{|c|c|c|c|}
\hline & Full sample & Migrants & Stayers \\
\hline \multicolumn{4}{|c|}{ Worker characteristics } \\
\hline Primary school & 0.563 & 0.587 & 0.563 \\
\hline High school & 0.303 & 0.280 & 0.304 \\
\hline College graduate & 0.101 & 0.094 & 0.101 \\
\hline Female & 0.372 & 0.210 & 0.376 \\
\hline \multicolumn{4}{|c|}{ Time variant characteristics } \\
\hline Log average wages in $t+1$ & 8.14 & 8.19 & 8.13 \\
\hline Employed at foreign establ. in year $t$ & 0.022 & 0.039 & 0.022 \\
\hline Employed at foreign establ. in year $t+1$ & 0.028 & 0.052 & 0.027 \\
\hline Employed at exporting establ. in year $t$ & 0.085 & 0.081 & 0.085 \\
\hline Employed at exporting establ. in year $t+1$ & 0.086 & 0.080 & 0.086 \\
\hline Number of observations & $1,005,010$ & 22,837 & 982,173 \\
\hline
\end{tabular}

Note: Worker characteristics in the upper panel are largely time invariant except for infrequent advances in educational attainment after entry into the formal sector labor force.

Sources: RAIS (1\% random sample), RDE-IED, and SECEX (1997-2001). 
and $2.8 \%$ of workers with only a primary school education are migrants.

This pattern exhibits only some regional variation across emigrant region. In all regions except for the South, workers with at least some college education are more likely than workers with lower levels of education to migrate; only in the South are workers with at least some college and workers with a primary or high school education equally likely to migrate. Formal sector migrants of all education levels are most likely to migrate from the Center-West region, consistent with the high total emigration from this state. At the state level within regions, there is some variability. Workers with only a primary school education, for instance, are more likely than the highest skilled workers to migrate out of the Northern states of Roraima (RR) and Tocantins, the Northeastern states of Alagoas (AL), Bahia (BA), Sergipe, Maranhão (MA), Rio Grande do Norte (RN), and the Center-West state of Mato Grosso (MT). Workers of all education levels are about equally likely to leave São Paulo state.

Migrant demographics vary across immigrant states. Migrating workers who arrive in the Southeast and the Distrito Federal (DF) around Brazil's capital are more likely to be high skilled. In contrast, formal sector migrants to the North are more likely to have only a primary school education. The main exception is Amazonas state. Our data indicate that the share of high skilled formal sector migrants to Amazonas state is greater than the share of low skilled formal sector migrants. These high skilled migrants most frequently move from within the Northern region.

Women are less likely to be formal sector migrants. This observation is consistent across all states and regions. The rates of migration for men and women are most similar in the Southern region. The average migrant is approximately two years younger than the average stayer. Youth aged 1517 are least likely to migrate, while young workers (18-24 years) are most likely to migrate.

Wages for formal sector migrants, both before and after the migration decision, are higher than wages for stayers. Before the migration decision, the average migrant earns average annual wages approximately $10 \%$ higher than stayers. The wage differential falls to $6 \%$ after the migration decision. Migration theory based on neoclassical human capital theory posits that workers search for jobs that offer the highest economic return in expected future wages. If the expected wage differential is a main determinant of the migration decision, the drop in the wage differential suggests that expectedly steeper or more cer- tain future wage paths could be important factors for the migration decision beyond the spot wage differential.

\section{(b) Job changes and migration}

Nationwide, between $40 \%$ and half of all formal sector workers change jobs per year, as Table 3 shows. In metropolitan areas, however, turnover is considerably smaller than the nationwide average, with only around one in four metropolitan workers changing jobs. Transfers of workers within firms but across states are only a minor component of formal sector migration. Migration is a remarkably important choice for workers with formal sector job changes (who neither retire nor exit the formal sector). Nationwide, roughly two-thirds of the job changing workers switch employment within-state (the proportion of the same state job changers in all job changers), but one-third migrate across state borders. ${ }^{16}$ Close to onehalf of all cross-border job changers move to a metropolitan area. Two to three in five workers with a job loss exit the formal sector at the annual horizon. ${ }^{17}$ The focus of the present paper lies on migrants with a successful formal sector reallocation.

Table 4 traces the 206,418 workers (about $20 \%$ of our sample) who changed jobs over a year between types of establishments - domestic or foreign owned establishments and nonexporting or exporting establishments - and offers a more manifest indication that globalization may be related to internal migration. The overall odds for a worker at a domestic establishment to change to a multinational enterprise $(0.026 /$ $0.954=0.027)$ are almost ten times smaller than for a multinational worker to change to another foreign owned establishment $(0.004 / 0.016=0.250) .{ }^{18}$ Similarly, the odds for a worker at a non-exporting establishment to change to an exporter $(0.047 / 0.874=0.054)$ are almost ten times smaller than for a worker at an exporter to change to another exporter $(0.026)$ $0.053=0.491)$.

As a consequence, the bulk of workers move between domestic and non-exporting establishments. But there are notable differences between migrants and stayers in their exposure to foreign owned and exporting establishments. Since migration frequencies are small at the annual horizon, apparently minor differences can matter for migration outcomes. Of the 206,418 workers with a job change in our sample, 20,684 $(10 \%)$ migrate across states. ${ }^{19}$ And of these 20,684 migrants, $733(3.5 \%)$ switch into a foreign owned establishment from a domestic establishment with their cross-state move; 1,027 $(5.0 \%)$ of the migrants switch into an exporting establishment

Table 3. Job retentions and changes, 1997-2001.

\begin{tabular}{|c|c|c|c|c|c|c|}
\hline & \multicolumn{3}{|c|}{ National } & \multicolumn{3}{|c|}{ Metropolitan areas } \\
\hline & 1997 & 1999 & 2001 & 1997 & 1999 & 2001 \\
\hline \multicolumn{7}{|l|}{ Job retention } \\
\hline Same location & 0.606 & 0.526 & 0.484 & 0.728 & 0.730 & 0.756 \\
\hline Transfer & 0.004 & 0.003 & 0.003 & 0.004 & 0.005 & 0.005 \\
\hline \multicolumn{7}{|c|}{ Job changes (frequencies conditional on no retention) } \\
\hline Same state & 0.255 & 0.176 & 0.148 & 0.468 & 0.428 & 0.514 \\
\hline Migrate metro & 0.051 & 0.042 & 0.055 & 0.014 & 0.014 & 0.019 \\
\hline Migrate other & 0.075 & 0.063 & 0.087 & 0.020 & 0.023 & 0.025 \\
\hline \multicolumn{7}{|c|}{ Other changes (frequencies conditional on no retention) } \\
\hline Retire & 0.040 & 0.060 & 0.071 & 0.035 & 0.038 & 0.041 \\
\hline Formal exit & 0.569 & 0.653 & 0.633 & 0.447 & 0.480 & 0.381 \\
\hline
\end{tabular}

Notes: End-years of annual worker continuations and transitions between jobs. Transfers are changes of establishment across state borders but within firms. Retirements include reported deaths on the job. Formal sector exits are to informal employment, unemployment, self-employment, or out of the labor force.

Sources: RAIS (1\% random sample, 1996-2001). 
Table 4. Establishment types and migration, 1997-2001.

\begin{tabular}{|c|c|c|c|c|c|c|}
\hline & \multicolumn{2}{|c|}{ Full sample } & \multicolumn{2}{|c|}{ Migrants } & \multicolumn{2}{|c|}{ Stayers } \\
\hline & Number & Share & Number & Share & Number & Share \\
\hline \multicolumn{7}{|c|}{ Workers with job change, switching establishment types } \\
\hline Domestic to foreign owned & 5,422 & 0.026 & 733 & 0.035 & 4,709 & 0.025 \\
\hline Foreign owned to domestic & 3,256 & 0.016 & 492 & 0.024 & 2,764 & 0.015 \\
\hline Non-exporting to exporting & 9,759 & 0.047 & 1,027 & 0.050 & 8,732 & 0.047 \\
\hline Exporting to non-exporting & 11,024 & 0.053 & 1,082 & 0.052 & 9,942 & 0.054 \\
\hline \multicolumn{7}{|c|}{ Workers with job change, remaining in establishment types } \\
\hline Domestic establishments & 196,922 & 0.954 & 19,381 & 0.937 & 177,541 & 0.956 \\
\hline Foreign owned establishments & 798 & 0.004 & 78 & 0.004 & 720 & 0.004 \\
\hline Non-exporting establishments & 180,360 & 0.874 & 18,243 & 0.882 & 162,117 & 0.873 \\
\hline Exporting establishments & 5,275 & 0.026 & 332 & 0.016 & 4,943 & 0.027 \\
\hline Number of observations & 206,418 & & 20,684 & & 185,734 & \\
\hline
\end{tabular}

Note: Sample restricted to workers who change establishments over a year.

Sources: RAIS (1\% random sample), RDE-IED, and SECEX (1997-2001).

from a non-exporting establishment after migration. Migrants are more likely to move to a job at a foreign owned or exporting establishment than the average worker: for non-migrants with a job change, the transition frequencies to a foreign owned or exporting establishment are only $2.5 \%$ and $4.7 \%$, respectively. Workers with a job change from an exporter to another exporter are more likely to be non-migrants $(2.7 \%)$ than migrants $(1.6 \%)$, however, possibly because exporters are regionally clustered.

We further restrict the sample in Table 5 to the 20,684 job changing migrants (as in the middle panel of Table 4) to decompose migrant transitions between relatively rich and poor states. ${ }^{20} \mathrm{~A}$ common assertion for Brazil is that migrants leave the relatively poor states in the North and Northeastern regions to relocate to the relatively rich states in the South and Southeast. While poor-to-rich migrations account for about $20 \%$ of our sample (4,352 workers), migrations from rich states to poor states make up roughly the same share $(4,081$ workers) as select states in the North and Northeast receive large flows of migrants.

This paper provides evidence for a possible explanation of this reverse migration - globalization in the form of new foreign owned and exporting establishments, particularly in the Northern states of Amazonas and Pará, which have benefited from governmental export promotion programs and export processing zones. In line with this hypothesis, a worker from a relatively rich state who migrates to a relatively poor state is more likely to move from a non-exporting establishment to an exporting establishment than is a poor-to-rich migrant (4.9\% of poor-to-rich migrants as compared to $4.0 \%$ of richto-poor migrants). Of course, industrial promotion programs may additionally contribute to these reverse migration patterns. Fiscal incentives in the Northeastern state of Ceará are an example. However, state-to-state migration patterns suggest that Ceará receives relatively few immigrants (also see Figure 4).

\section{(c) Employer characteristics}

Table 6 shows that workers in foreign owned establishments are more educated on average than workers in their domestic establishment counterparts. Almost $20 \%$ of workers at a foreign owned establishment are college graduates, while only $10 \%$ of workers at domestic establishments have a college degree. Workers at foreign owned establishments are on average one-half year younger and less likely to be female than workers at domestic establishments. Workers in exporting establishments are also younger and more likely male than workers in non-exporting establishments. However, workers in exporting establishments are on average less educated. $58 \%$ of exporting establishment workers have only a primary school education.

Wage differentials between current employment and expected future employment are a widely documented determinant of migration. Exporters and foreign owned establishments typically pay higher wages, partly because of

Table 5. Establishment types and migration transitions, 1997-2001.

\begin{tabular}{|c|c|c|c|c|c|c|c|c|}
\hline & \multicolumn{8}{|c|}{ Migrants: of which transition is } \\
\hline & \multicolumn{2}{|c|}{ Rich-Rich } & \multicolumn{2}{|c|}{ Poor- Poor } & \multicolumn{2}{|c|}{ Poor-Rich } & \multicolumn{2}{|c|}{ Rich-Poor } \\
\hline & Number & Share & Number & Share & Number & Share & Number & Share \\
\hline \multicolumn{9}{|c|}{ Workers with job change, switching establishment types } \\
\hline Domestic to foreign owned & 474 & 0.050 & 43 & 0.016 & 155 & 0.036 & 61 & 0.015 \\
\hline Foreign owned to domestic & 262 & 0.027 & 27 & 0.010 & 76 & 0.017 & 127 & 0.031 \\
\hline Non-exporting to exporting & 558 & 0.058 & 44 & 0.016 & 174 & 0.040 & 199 & 0.049 \\
\hline Exporting to non-exporting & 545 & 0.057 & 110 & 0.041 & 222 & 0.051 & 205 & 0.050 \\
\hline \multicolumn{9}{|c|}{ Workers with job change, remaining in establishment types } \\
\hline Domestic establishments & 8,778 & 0.918 & 2,616 & 0.974 & 4,101 & 0.942 & 3,886 & 0.952 \\
\hline Foreign owned establishments & 50 & 0.005 & 1 & 0.0003 & 20 & 0.005 & 7 & 0.002 \\
\hline Non-exporting establishments & 8,255 & 0.863 & 2,437 & 0.907 & 3,917 & 0.900 & 3,634 & 0.890 \\
\hline Exporting establishments & 206 & 0.022 & 44 & 0.016 & 39 & 0.009 & 43 & 0.011 \\
\hline Number of observations & 9,564 & & 2,687 & & 4,352 & & 4,081 & \\
\hline
\end{tabular}

Note: Sample restricted to workers who migrate and change establishments over a year.

Sources: RAIS (1\% random sample), RDE-IED, and SECEX (1997-2001). 
Emigrant shares by state

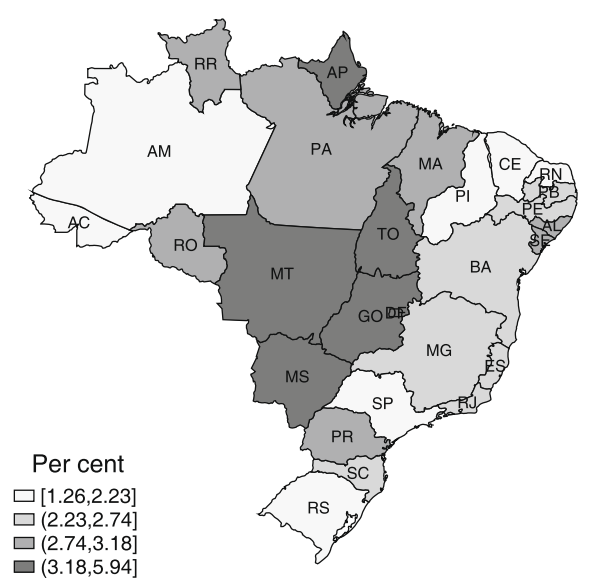

Immigrant shares by state

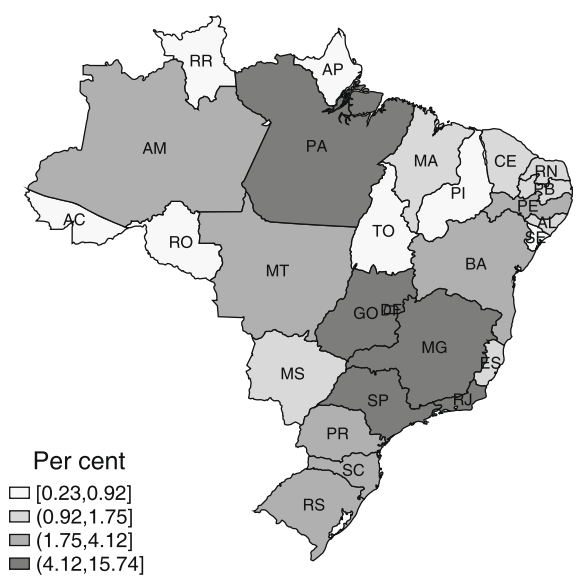

Source: RAIS (1\% random sample), 1997-2001.

Figure 4. Emigration and immigration frequencies by state, 1997-2001.

Table 6. Average workforce characteristics, by establishment type, 1997-2001.

\begin{tabular}{|c|c|c|c|c|c|}
\hline & Full sample & Foreign & Domestic & Exporting & Non-exporting \\
\hline Primary school & 0.563 & 0.362 & 0.568 & 0.577 & 0.562 \\
\hline High school & 0.303 & 0.363 & 0.302 & 0.303 & 0.303 \\
\hline Some college & 0.033 & 0.083 & 0.032 & 0.040 & 0.032 \\
\hline College graduate & 0.101 & 0.193 & 0.099 & 0.081 & 0.103 \\
\hline Female & 0.372 & 0.259 & 0.375 & 0.243 & 0.384 \\
\hline Age & 34.0 & 33.5 & 34.0 & 32.7 & 34.1 \\
\hline Number of observations & $1,005,010$ & 22,071 & 982,939 & 85,677 & 919,333 \\
\hline
\end{tabular}

Sources: RAIS (1\% random sample), RDE-IED, and SECEX (1997-2001).

more skilled workforces (see Table 6) and partly because of firm fixed effects in compensation (Menezes-Filho, Muendler, \& Ramey, 2008). Beyond differences in spot wages, expected wage profiles provide incentives for job changes and migration. In Figure 3, we graph the average log wage for workers over years of tenure at the establishment, by establishment type. The tenure wage profile for foreign owned establishments is considerably steeper than the tenure wage profile for domestic owned establishments, while there appears to be only a small difference between the tenure wage paths for exporting and non-exporting establishments. In fact, based on evidence from linear prediction, an additional year of tenure at a non-exporting establishment is associated with $2.1 \%$ higher wages, while an additional year at an exporting establishment relates to $2.9 \%$ higher wages. Meanwhile, an additional year of tenure at a multinational enterprise predicts a wage increase by more than double the amount at a domestic owned establishment (4.5\% as compared to $2.1 \%)$.

\section{(d) Emigrant and immigrant states}

Figure 4 maps the frequency of formal sector emigration and immigration by state. Formal sector emigrants are most likely to come from the Northern regions. More than one in twenty workers from Tocantins in the sample migrated to another state during 1997-2001. Over 3\% of workers in Sergipe, Rondônia (RO), Roraima, and Amapá (AP) leave for another state. The share of emigrants in the Center-West region is similarly high. Close to $5 \%$ of workers from Mato Grosso and the Distrito Federal are migrants. Emigrants are least likely to come from states in the South and Southeast. Only 1.5\% and $1.7 \%$ of workers in Rio Grande do Sul (RS) and São Paulo, respectively, migrate to another state.

Immigration to the Southeast dominates. Over 15\% of the sample workforce head to São Paulo state, while $6.2 \%$ and 5.8\% move to Minas Gerais (MG) and Rio de Janeiro states, respectively. The states of Goiás and the Distrito Federal in the Center-West, Pará in the North, and Bahia in the Northeast, however, also receive considerable flows of immigrants. This stands in stark contrast to the common assertion that the typical migrant flow in Brazil runs from North to South, or from relatively poor regions to relatively rich regions.

Although a large part of formal sector migration in Brazil is regional, there is substantial migration from great distances. ${ }^{21}$ Emigrants from Acre in the North are most likely to move across the country to Alagoas state in the Northeast and immigrants in Espírito Santo (ES) in the Southeast are most frequently from Alagoas. Not surprisingly, 14 out of 27 states send the highest shares of migrants to São Paulo. Meanwhile, among emigrants from São Paulo state during 1997-2001, almost $70 \%$ moved within the South or Southeast, yet almost $21 \%$ migrated to states in the Northern regions, and $13 \%$ migrated to the Center-West region. Immigrants to Amazonas state are most likely to arrive from within the Northern region, while close to $3 \%$ of formal sector migrants moving to Amazonas state arrive from the South and Southeast regions.

\section{ESTIMATION OF THE MIGRATION DECISION}

We now turn to multivariate analysis for more systematic evidence on the relationship between formal sector migration and 
Brazil's increasing integration into the global economy. The approach allows us to simultaneously condition on multiple covariates associated with formal sector migration flows, and to discern their importance as predictors for migration. We first treat the self-selection problem inherent in the migration decision and estimate a maximum likelihood model of selectivity corrected wages (Heckman, 1979). On the basis of these predicted wages, we follow the Dahl (2002) methodology and account for a migrant's choice between multiple destinations.

\section{(a) An econometric model of migration with self-selection}

The neoclassical migration model takes expected utility differentials as the underlying forces for migration. Rational individuals optimize expected lifetime utility, given the expected earnings differential and costs to migrate. Non-pecuniary factors such as differences in regional amenities or land values may also enter the utility function and influence the migration decision. Econometric studies analyzing migration decisions typically depart from a Mincer (1974) wage regression as follows

$Y_{i}=\alpha X_{i}+\beta M_{i}+\delta Z_{s}+\epsilon_{i}$,

where $Y_{i}$ are $\log$ wages for individual $i, X_{i}$ is a vector of individual characteristics, $M_{i}$ is a binary variable equal to one if the worker migrates, $Z_{s}$ is a vector of characteristics for state $s$, and $\epsilon_{i}$ is the error term.

Estimation of the return to migration based on a comparison of wages as in Eqn. (1) between migrants and stayers may be biased due to self-selection. A correctly specified $\beta$ could only be recovered directly if we observed a worker once randomly induced to migrate and once to stay. Simplifying Eqn. (1), $\beta$ measures the expected difference in wage outcomes for a worker, conditional on migration, that is

$E(\beta \mid X, Z, M=1)=E\left(Y_{m} \mid X, Z, M=1\right)-E\left(Y_{s} \mid X, Z, M=1\right)$,

where $E(\cdot \mid X, Z, M=1)$ is the conditional expectation function (conditional on migration and a vector of covariates), and $Y_{m}$ and $Y_{s}$ are wage outcomes for a migrant and a stayer. The researcher knows the first element of the term, but it is impossible to observe the second part of the term-wages of a stayer conditional on the counterfactual circumstance that he migrates.

Consider the following decomposition of observed outcome variables: wages of migrants conditional on migration and wages of stayers conditional on staying,

$$
\begin{aligned}
E\left(Y_{m} \mid X, Z, M=1\right) & -E\left(Y_{s} \mid X, Z, M=1\right)+E\left(Y_{s} \mid X, Z, M=1\right) \\
& -E\left(Y_{s} \mid X, Z, M=0\right) .
\end{aligned}
$$

The first two terms of the expression represent the parameter of interest $\beta$, while the last two terms represent the self-selection bias - the difference in counterfactual outcomes depending on whether a worker migrates or stays. Self-selection may occur if migrants are selected by employers in the immigration state on the basis of worker characteristics or if migrants sort themselves into regions and occupations with the highest expected relative earnings.

Our estimation procedure derives from the Roy (1951) model of self-selection as extended by Dahl (2002). The approach allows the migration decision and the economic returns from migration to be determined simultaneously.

Consider the migration decision. An individual chooses to migrate depending on the gains and costs of migration. Neglecting other regional attributes for a moment, an individual will migrate if the expected wage differential from migrating exceeds the associated costs
$Y_{m i}-Y_{s i}>C_{i}$,

where $Y_{m i}$ and $Y_{s i}$ are wages in the migration state and wages in the home state, respectively, and $C_{i}$ are the associated moving costs. Following the literature, we suppose that a worker's propensity to migrate is a linear function of the wage differential as well as individual, $X_{i}$, and state, $Z_{s}$, characteristics

$M_{i}=\alpha_{0}+\alpha_{1}\left[Y_{m i}-Y_{s i}\right]+\alpha_{2} X_{i}+\alpha_{3} Z_{s}+\epsilon_{i}$,

where $M_{i}$ is the migration indicator.

As discussed, the econometrician cannot observe wage outcomes for an individual in both the migrant state $\left(Y_{m i}\right)$ and the stayer state $\left(Y_{s i}\right)$. To overcome the self-selection problem, we first estimate the observed wage as the outcome of a migrate-or-stay decision, using maximum likelihood for the selection correction (Heckman, 1979). ${ }^{22}$ Our baseline estimation is as follows. The migration selection equation includes worker and state characteristics. The wage outcome equation excludes state level characteristics under the assumption that worker and employer characteristics exhaustively predict earnings. The Dahl (2002) approach then estimates the migration decision as predicted by selectivity corrected wage differentials, worker and state characteristics. In addition to conventional regressors, our data also allow us to include employer characteristics in the migration regression. In a robustness check beyond the standard Dahl (2002) approach, we ultimately also account for workers who change jobs within-state and whose presence in the non-migrant group might affect the estimates. For now, we turn to the baseline estimates.

\section{(b) Selectivity corrected wage outcomes}

Table 7 presents the results from a selectivity corrected wage outcome estimation using maximum likelihood. Column (1) reports selectivity corrected coefficients for our baseline specification. All regressors in the outcome (wage) equation are highly significant and exhibit the expected sign. ${ }^{23}$ Worker specific variables in the migration equation are highly significant and corroborate the evidence from Section 4: women are less likely to migrate than men; workers with at least some college are more likely to migrate than less educated workers; migration is decreasing in age. State level information is also largely consistent with the literature: the higher is the state's urbanization rate, log state average wages, and the state's log value added in agriculture and manufacturing, the less likely is a worker to migrate. Interestingly, GDP per capita at $t$ correlates significantly positively with migration. A formal sector worker is more likely to migrate if he resides in a highincome state, in contrast to common priors. ${ }^{24}$ The sign is also consistent with the economic rationale that skilled formal sector emigrants from high income states may expect to find formal sector jobs with steeper or more certain wage paths at employers in lower income states. Column (2) includes state level dummies as controls.

We augment our baseline specification to include employer level controls both before and after the migration decision. Identification of the selectivity corrected coefficients in column (2) derives from the excluded state level sectoral compositions in the outcome equation. After including employer level information, these state level characteristics arguably matter little for wage determination, but are still important factors for migration. Column (3) presents results with employer controls after the migration decision in the outcome equation, and the specification in column (4) also includes establishment controls before the migration decision in the outcome equation. Establishment controls include average log wages, the log number of workers, the share of female workers, and the share 
Table 7. Selectivity corrected wage estimation

\begin{tabular}{|c|c|c|c|c|}
\hline $\begin{array}{l}\text { Dependent variable: } \\
\text { log wage in } t+1\end{array}$ & (1) & $(2)$ & (3) & (4) \\
\hline \multicolumn{5}{|c|}{ Outcome equation: Log Wage } \\
\hline Female & $\begin{array}{c}-0.408^{* *} \\
(0.019)\end{array}$ & $\begin{array}{l}-0.417^{* *} \\
(0.020)\end{array}$ & $\begin{array}{l}-0.250^{* *} \\
(0.016)\end{array}$ & $\begin{array}{l}-0.192^{* *} \\
(0.016)\end{array}$ \\
\hline High school graduate & $\begin{array}{l}0.463^{* *} \\
(0.011)\end{array}$ & $\begin{array}{l}0.445^{* *} \\
(0.011)\end{array}$ & $\begin{array}{l}0.223^{* *} \\
(0.010)\end{array}$ & $\begin{array}{l}0.223^{* *} \\
(0.011)\end{array}$ \\
\hline Some college & $\begin{array}{l}1.183^{* *} \\
(0.026)\end{array}$ & $\begin{array}{l}1.152^{* *} \\
(0.025)\end{array}$ & $\begin{array}{l}0.592^{* *} \\
(0.021)\end{array}$ & $\begin{array}{l}0.527^{* *} \\
(0.022)\end{array}$ \\
\hline College graduate & $\begin{array}{l}1.640^{* *} \\
(0.018)\end{array}$ & $\begin{array}{l}1.610^{* *} \\
(0.018)\end{array}$ & $\begin{array}{l}0.932^{* *} \\
(0.016)\end{array}$ & $\begin{array}{l}0.894^{* *} \\
(0.017)\end{array}$ \\
\hline Age at $t+1$ & $\begin{array}{l}0.065^{* *} \\
(0.003)\end{array}$ & $\begin{array}{l}0.066^{* *} \\
(0.003)\end{array}$ & $\begin{array}{l}0.033^{* *} \\
(0.002)\end{array}$ & $\begin{array}{l}0.027^{* *} \\
(0.003)\end{array}$ \\
\hline Age at $t+1$ squared & $\begin{array}{l}-0.001^{* *} \\
(0.00004)\end{array}$ & $\begin{array}{l}-0.001^{* *} \\
(0.00004)\end{array}$ & $\begin{array}{l}-0.0003^{* *} \\
(0.00003)\end{array}$ & $\begin{array}{l}-0.0002^{* *} \\
(0.00003)\end{array}$ \\
\hline \multicolumn{5}{|c|}{ Selection equation: Migrate } \\
\hline Female & $\begin{array}{c}-0.337^{* *} \\
(0.007)\end{array}$ & $\begin{array}{l}-0.337^{* *} \\
(0.007)\end{array}$ & $\begin{array}{l}-0.335^{* *} \\
(0.007)\end{array}$ & $\begin{array}{l}-0.334^{* *} \\
(0.007)\end{array}$ \\
\hline High school graduate & $\begin{array}{l}-0.017^{*} \\
(0.007)\end{array}$ & $\begin{array}{l}-0.017^{*} \\
(0.007)\end{array}$ & $\begin{array}{l}-0.011 \\
(0.007)\end{array}$ & $\begin{array}{l}-0.006 \\
(0.007)\end{array}$ \\
\hline Some college & $\begin{array}{l}0.132^{* *} \\
(0.015)\end{array}$ & $\begin{array}{l}0.132^{* *} \\
(0.015)\end{array}$ & $\begin{array}{l}0.142^{* *} \\
(0.015)\end{array}$ & $\begin{array}{l}0.152^{* *} \\
(0.015)\end{array}$ \\
\hline College graduate & $\begin{array}{l}0.087^{* *} \\
(0.010)\end{array}$ & $\begin{array}{l}0.087^{* *} \\
(0.010)\end{array}$ & $\begin{array}{l}0.095^{* *} \\
(0.010)\end{array}$ & $\begin{array}{l}0.107^{* *} \\
(0.010)\end{array}$ \\
\hline Age at $t$ & $\begin{array}{c}-0.010^{* *} \\
(0.0003)\end{array}$ & $\begin{array}{l}-0.010^{* *} \\
(0.0003)\end{array}$ & $\begin{array}{l}-0.010^{* *} \\
(0.0003)\end{array}$ & $\begin{array}{c}-0.010^{* *} \\
(0.0003)\end{array}$ \\
\hline Urbanization at $t$ & $\begin{array}{l}-0.131^{* *} \\
(0.049)\end{array}$ & $\begin{array}{l}-0.131^{* *} \\
(0.049)\end{array}$ & $\begin{array}{c}-0.134^{* *} \\
(0.049)\end{array}$ & $\begin{array}{c}-0.136^{* *} \\
(0.050)\end{array}$ \\
\hline GDP per capita at $t$ & $\begin{array}{l}0.076^{* *} \\
(0.009)\end{array}$ & $\begin{array}{l}0.076^{* *} \\
(0.009)\end{array}$ & $\begin{array}{l}0.078^{* *} \\
(0.009)\end{array}$ & $\begin{array}{l}0.077^{* *} \\
(0.009)\end{array}$ \\
\hline $\begin{array}{l}\text { Log average state } \\
\text { wages at } t\end{array}$ & $\begin{array}{c}-0.209^{* *} \\
(0.029)\end{array}$ & $\begin{array}{c}-0.209^{* *} \\
(0.029)\end{array}$ & $\begin{array}{c}-0.209^{* *} \\
(0.029)\end{array}$ & $\begin{array}{c}-0.202^{* *} \\
(0.030)\end{array}$ \\
\hline $\begin{array}{l}\text { Log value added in } \\
\text { agriculture at } t\end{array}$ & $\begin{array}{c}-0.010^{* *} \\
(0.004)\end{array}$ & $\begin{array}{c}-0.010^{* *} \\
(0.004)\end{array}$ & $\begin{array}{c}-0.012^{* *} \\
(0.004)\end{array}$ & $\begin{array}{c}-0.013^{* *} \\
(0.004)\end{array}$ \\
\hline $\begin{array}{l}\text { Log value added in } \\
\text { manufacturing at } t\end{array}$ & $\begin{array}{c}-0.097^{* *} \\
(0.009)\end{array}$ & $\begin{array}{c}-0.097^{* *} \\
(0.009)\end{array}$ & $\begin{array}{c}-0.095^{* *} \\
(0.009)\end{array}$ & $\begin{array}{c}-0.092^{* *} \\
(0.009)\end{array}$ \\
\hline $\begin{array}{l}\text { Log value added in } \\
\text { services at } t\end{array}$ & $\begin{array}{l}0.050^{* *} \\
(0.012)\end{array}$ & $\begin{array}{l}0.050^{* *} \\
(0.012)\end{array}$ & $\begin{array}{l}0.049^{* *} \\
(0.012)\end{array}$ & $\begin{array}{l}0.046^{* *} \\
(0.012)\end{array}$ \\
\hline $\begin{array}{l}\text { Fixed effects: state at } \\
t+1\end{array}$ & & Yes & Yes & Yes \\
\hline $\begin{array}{l}\text { Establishment controls } \\
\text { at } t+1\end{array}$ & & & Yes & Yes \\
\hline $\begin{array}{l}\text { Establishment controls } \\
\text { at } t\end{array}$ & & & & Yes \\
\hline $\begin{array}{l}\text { Number of } \\
\text { observations }\end{array}$ & $1,005,010$ & $1,005,010$ & $1,004,549$ & $1,003,876$ \\
\hline
\end{tabular}

Notes: Establishment controls include average wages, number of workers, the share of female workers, and the share of workers in eight age groups, four education groups, and five occupational groups. Robust standard errors are in parentheses.

Sources: RAIS (1\% random sample) and IBGE (1997-2001).

* Significance at the 5\% level.

** Significance at the $1 \%$ level.

of workers in eight age groups, four education groups, and five occupational groups. ${ }^{2}$

In our preferred specification with employer controls before and after the migration decision (column 4), all regressors in the wage equation are still highly significant and exhibit the expected signs. After inclusion of employer level information, the bias corrected coefficients on the individual characteristics move towards zero as expected, but coefficients in the selection equation show negligible changes. The coefficients on employer level controls in the outcome equation, not reported in Table 7, have expected signs - employment at an establishment with higher average wages both before and after migration is positively correlated with a worker's wages.

\section{(c) Globalization and formal sector migration}

We predict selectivity corrected wages for workers in all 27 Brazilian states as migrants and stayers with the coefficient estimates from column (4) of Table 7. We then follow Dahl (2002) and extend the Roy (1951) model to the multiple destination migration decision by grouping workers with similar characteristics into worker cells. We define cells by emigration state, year, age, ${ }^{26}$ gender, and education. ${ }^{27}$ We then stack observations for each emigration state-immigration state pair to generate a matrix of migration probabilities calculated for each state $s$ as the fraction of workers in the cell who migrate from state $s$ to state $m$ in year $t$. The transformed data set includes 135,044 cells with an average of 187 workers per cell. ${ }^{28}$

We then adapt Eqn. (2) to include $M_{c s m}$, the probability that a worker from cell $c$ migrates from state $s$ to state $m$, as follows:

$M_{c s m}=\alpha_{0}+\alpha_{1}\left[\widehat{Y}_{c m}-\widehat{Y}_{c s}\right]+\alpha_{2} X_{c}+\alpha_{3} Z_{s}+\epsilon_{c m s}$,

where $c$ denotes the 135,044 cell observations, $\widehat{Y}_{c m}$ and $\widehat{Y}_{c s}$ are computed as the cell average of the bias corrected predicted wages from the Heckman (1979) selectivity correction for migrants and stayers, $X_{c}$ includes cell characteristics (gender, age, and educational attainment), and $Z_{s}$ includes state level characteristics.

To study the relationship between formal sector migration and market oriented policy reforms in Brazil, our main specification augments Eqn. (3) so that $X_{c}$ includes cell average employer characteristics. For instance, our analysis relates the following predictors to cell $c$ 's probability of migration: the share of workers in cell $c$ employed at a foreign owned establishment, the share of workers in cell $c$ employed at an exporting establishment, and the cell average establishment level tenure wage profile. We measure the tenure wage profile as the gradient between establishment average wages for workers with less than a year of tenure and establishment average wages for workers with 30 years of tenure (see Figure 3). We also augment the vector $Z_{s}$ to include state level globalization related characteristics, such as the state share of foreign owned establishments, the state share of exporting establishments, state level log of exports, and state level log of imports, as additional regressors. The latter exports and imports regressors serve as controls for a location's exposure to global competition and as such are not reported.

Table 8 reports results from the ordinary least squares estimation of Eqn. (3). We regress worker cell migration probabilities on cell characteristics and state characteristics, pooling the migration probabilities of all cells from all states $s$ to all states $m$. All regressions are weighted by the number of workers in each cell, standard errors are clustered at the emigration state level to account for spatial correlation of errors, and annual time dummies are included to control for economy wide shocks affecting all workers (e.g., the Brazilian currency crisis in 1999).

Column (1) reports estimation results for a simple model in which the interstate wage differential and worker characteristics predict the migration decision. The result, after controlling for worker characteristics like gender, age, and educational 
attainment, and using selectivity corrected wage differentials, suggests that interstate wage differentials are positively correlated with a worker's decision to migrate. A $1 \%$ increase in the spot wage differential is associated with a $0.2 \%$ increase in the probability of cross-state migration. The remaining cell specific variables are highly significant and corroborate the evidence from Section 4: women are less likely to migrate than men, while the probability of migration is increasing in the level of education and decreasing in age. In column (2), we add emigration state fixed effects, emigration state time varying controls, and emigration establishment controls, including the cell average establishment level 30-year tenure wage profile. The expectation of higher future wages in the current establishment significantly reduces the likelihood of migration, and the interstate wage differential remains significantly positively correlated with the migration frequency.
Specification (3) introduces employer characteristics related to globalization, including the share of the cell employed in a foreign owned establishment and the share of the cell employed in an exporting establishment. Employment at a multinational firm is not statistically significantly associated with migration. But results suggest that employment at an exporting establishment is negatively related to internal migration. A one standard deviation increase in the share of the cell employed at exporting establishments (approximately 10\%) is associated with a $3 \%$ decrease in the probability of migration. This finding is consistent with the idea that the business success of exporting establishments informs workers' migration decisions.

Including state level controls related to globalization in column (4) offers similar conclusions. The share of the cell employed at an exporting establishment remains negatively correlated with the probability of migration. Controlling for

Table 8. Formal sector migration in Brazil.

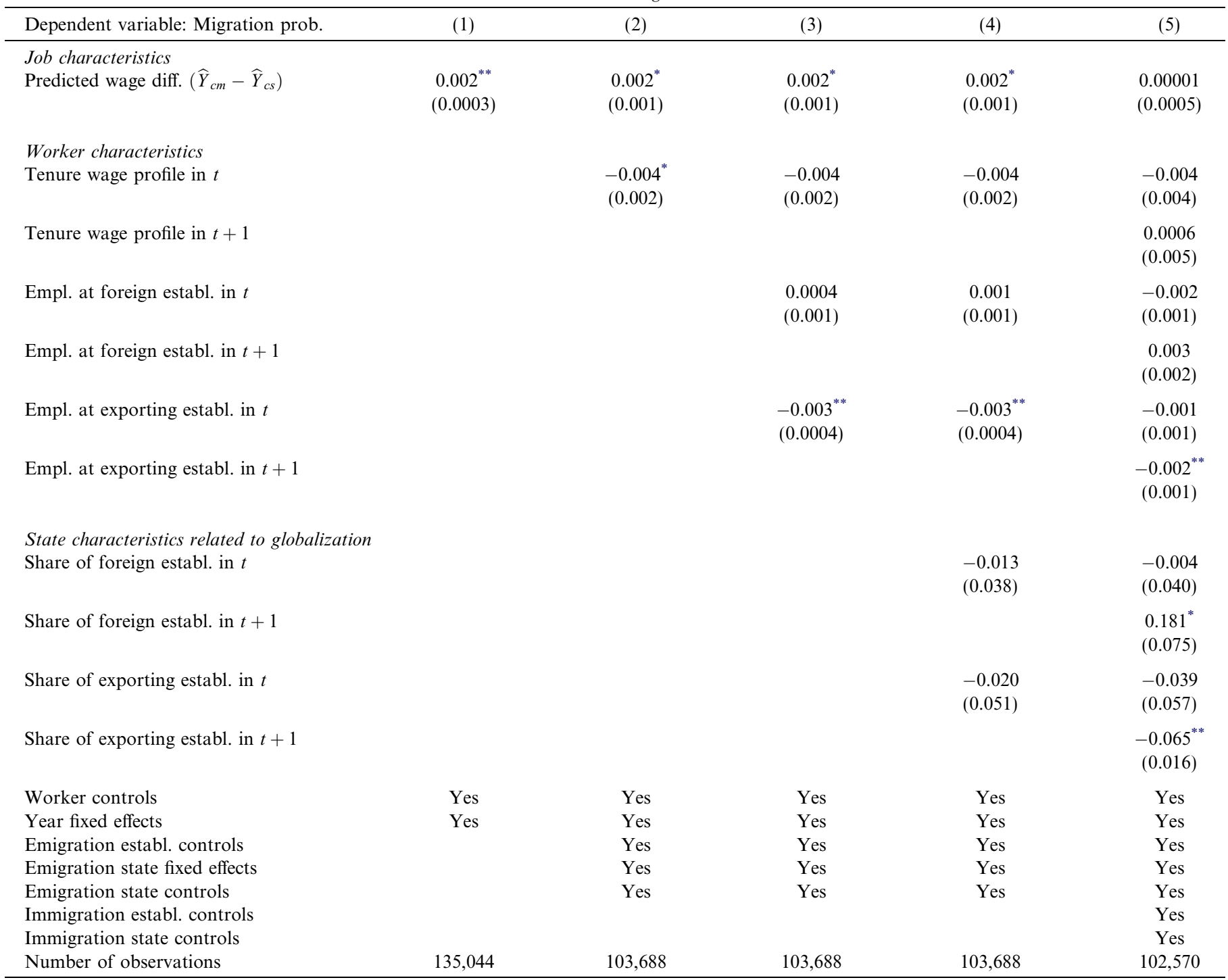

Notes: Worker cells are formed by eight age, two gender, and four educational attainment categories. State level controls include urbanization rates, GDP per capita, average state wages, value added from agriculture, services, and manufacturing, exports and imports. Establishment controls include average wages, number of workers, the share of female workers, and the share of workers in eight age groups, four education groups, and five occupational groups. Regressions are weighted by cell size. Robust standard errors, clustered at the state level, are in parentheses.

Sources: RAIS (1\% random sample), IBGE, RDE-IED, and SECEX (1997-2001).

${ }^{*}$ Significance at the $5 \%$ level.

${ }^{* *}$ Significance at the $1 \%$ level. 
Table 9. Formal sector migration in Brazil: Workers with a job change.

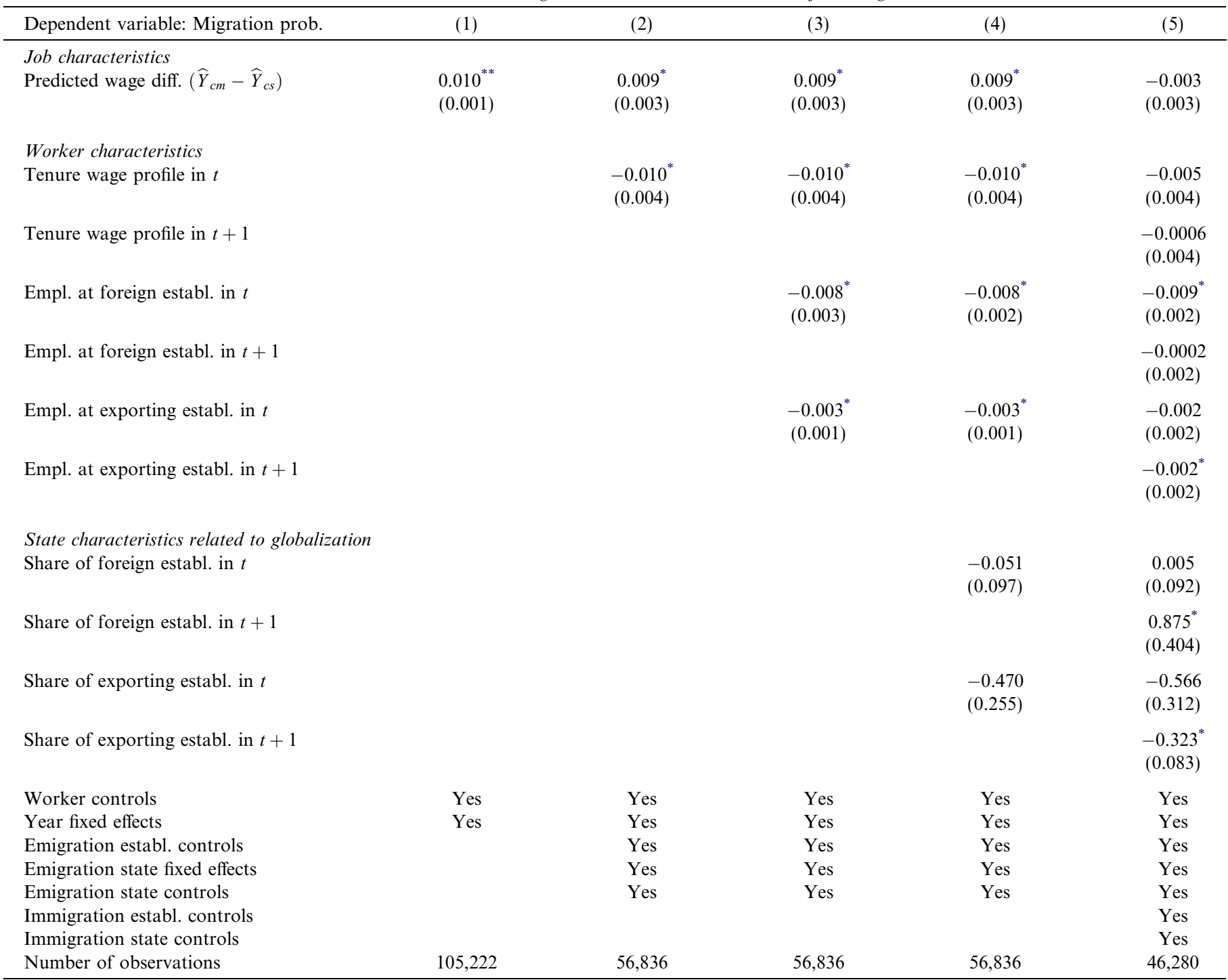

Notes: The sample is restricted to workers with a year-to-year job change. Worker cells are formed by eight age, two gender, and four educational attainment categories. State level controls include urbanization rates, GDP per capita, average state wages, value added from agriculture, services, and manufacturing, exports and imports. Establishment controls include average wages, number of workers, the share of female workers, and the share of workers in eight age groups, four education groups, and five occupational groups. Regressions are weighted by cell size. Robust standard errors, clustered at the state level, are in parentheses.

Sources: RAIS (1\% random sample), IBGE, RDE-IED, and SECEX (1997-2001).

${ }^{*}$ Significance at the $5 \%$ level.

${ }^{* *}$ Significance at the $1 \%$ level.

the share of exporting establishments in the state, an increase in the share of the cell employed at an exporting establishment of $10 \%$ (one standard deviation) relates to a $3 \%$ drop in the probability of migration.

The descriptive evidence in Table 4 above showed that workers at exporters and multinational enterprises are markedly more likely to move to another exporter or multinational enterprise when changing jobs, than workers at non-exporters or domestic establishments. A concern is therefore that omitting variables related to the worker's employment and location after migration could drive results in columns (1)-(4). We address this concern by including variables for the immigration state and immigration establishment in specification (5). ${ }^{29}$ Employment at an exporting establishment in the initial year continues to be negatively related to internal migration, though it loses significance. Migration is significantly nega- tively related to employment at an exporter after the migration decision and the share of exporters at the immigration location. These results are in line with evidence in Table 4 that non-migrants with a job change more often find re-employment at exporting establishments than migrants.

Migration is significantly positively related with a larger share of multinational enterprises at the immigration location, however. A $10 \%$ increase in the concentration of foreign owned establishments at potential immigration locations is associated with a $1.8 \%$ increase in the migration rate. This result is consistent with the idea that locations which attract multinational enterprises are also economically appealing locations for domestic formal sector migrants.

The results of our multivariate analysis corroborate the descriptive findings in Section 4 and provide support for the idea that globalization acts on internal migration through 
the growth of employment opportunities at locations with a high concentration of foreign owned establishments and the stability of employment at exporting establishments: a $10 \%$ increase in exporter employment relates to a 3\% reduced probability of migration, and a $10 \%$ increase in the concentration of foreign owned establishments at potential immigration locations relates to a $2 \%$ increase in the migration rate. The importance of foreign owned establishments in the immigration region, beyond the spot wage, is consistent with the economic rationale that migrants can expect benefits beyond the spot wage differential, such as steeper wage paths at foreign owned establishments (Figure 3) or more favorable labor market conditions in areas where multinational enterprises locate. The magnitudes of the migration flow changes, predicted by exporter employment and the concentration of foreign owned establishments at the destination location, are potentially large, given an annual overall migration rate of only $2 \%$.

\section{(d) Robustness check}

We now check the robustness of the main results in Table 8 to within-state job changes. All migrants change jobs. But there are job changers who do not move across state borders and become part of the non-migrant group. Table 3 documented that between one-half and two-thirds of all workers remain in the same job from year-to-year. Among workers with a year-over-year job change, approximately one in five workers remains in the same state. Until now, our analysis has considered both of these sets of workers as identical stayers. But within-state job changers arguably also respond to wage differences in their job change, so that the wage prediction for migrants in Eqn. (1) is understated even after migration selectivity correction because cross-state migrants might only move in response to an additional wage differential that compensates for cross-state migration costs. As a consequence, we might expect the coefficient on the wage differential in Eqn. (3) for the probability of cross-state migration to be underestimated.

Our current framework relating globalization factors to interstate migration can be decomposed into two decisions: first, the decision to change jobs or remain in the same job; and second, conditional on job change, the decision to move within-state or migrate out of state. The conventional Dahl (2002) framework does not separately identify the two decisions. A worker without a job change typically does not migrate out of state (except for the rare occasion when a worker transfers within a firm) and a worker who migrates across state lines must change jobs.

In order to separate the cross-state migration decision from the within-state job change decision, we limit the sample to workers with a job change. In Brazil, close to $80 \%$ of the approximately $40 \%$ of workers who separate from their job are laid off by the employer (only $20 \%$ quit their current job voluntarily). So, for most workers, the job-separation decision is not under the worker's control. For four in five workers with a job separation, the only decision is whether to move withinstate or to migrate across state borders. So, we can estimate the likelihood of formal sector migration across states conditional on a worker's job change year over year. When we further restrict the robustness sample to only workers who were laid off, excluding quitters, we find largely comparable results.

As in the conventional Dahl (2002) framework from before, we first treat the self-selection problem inherent in the migration decision and estimate a maximum likelihood model of selectivity corrected wages following Heckman (1979), now only for the subsample of workers with a year-to-year job change. Appendix Table A.1 reports the selectivity corrected maximum likelihood estimates. Results are comparable to the earlier results in Table 7 for the complete set of workers. ${ }^{30}$

From this regression, we predict selectivity corrected wages for the set of job changing workers in all 27 Brazilian states as migrants (across-state job changers) and as stayers (withinstate job changers). We then follow Dahl (2002) to estimate the worker's multi-destination migration decision as described in Section 5. Table 9 reports results from Eqn. (3) for the subsample of workers with a job change. As in Table 8, all regressions are weighted by the number of workers in each cell, standard errors are clustered at the emigration state level, and annual time dummies are included.

Controlling for cell characteristics, time varying emigration establishment characteristics, and emigration state characteristics in column (4), the interstate wage differential remains positively significantly related to the worker's cross-state migration decision. For the subsample of workers with a job change, a $1 \%$ increase in the spot wage differential is now associated with a $0.9 \%$ increase in the probability of migration. This coefficient estimate is roughly five times larger than the one in Table 8. In other words, the same wage differential induces workers who just suffered a separation five times more frequently into a cross-state migration than the average worker. This is consistent with the idea that migration fixed costs are particularly high for workers with a stable employment so that wage differentials need to be five times higher to trigger cross-state migration for an average worker than for a worker who just suffered a separation. More precisely, a one standard deviation higher wage differential is associated with a $1.8 \%$ increase in the migration probability for all workers and a $8.7 \%$ increase in the migration probability for workers with a job change. As expected, the negative omitted variable bias from non-migrants with a job change reinforces the negative selfselection into job change, by which low earning workers are more likely to change jobs. Similarly, the expectation of higher future wages in the current establishment, as proxied by the establishment level 30-year tenure wage profile, significantly reduces the likelihood of cross-state migration.

Our focal results remain largely unchanged. Controlling for the share of exporting and foreign owned establishments in the state, employment at an exporting establishment is negatively correlated with formal sector interstate migration. A $1 \%$ increase in the share of the cell employed at an exporting establishment reduces the probability of migration by $0.3 \%$. For the subsample of job changers, prior employment at a foreign owned establishment is also negatively associated with crossstate migration. A $1 \%$ increase in the cell share employed at a foreign owned establishment is related to a reduction in the frequency of migration of approximately $0.8 \%$. This evidence is consistent with the geographic concentration of foreign owned and exporting establishments. Finally, migration remains positively correlated with the share of foreign enterprises at the immigration location (column (5)).

\section{CONCLUDING REMARKS}

This paper investigates how factors related to globalization are associated with internal migration flows in a developing country. Using Brazil's comprehensive linked employer-employee data that cover all federal states and sectors of the economy, we document that domestic formal sector migration flows are directed to destinations with a high concentration of foreign owned establishments during 1997-2001. Workers who are employed at exporting establishments are less likely 
to migrate. Our estimation approach corrects for the self-selection of migrants and controls for interstate wage differentials as well as worker and state characteristics. Workers face a joint decision of whether to change jobs and, conditional on job change, whether to move within-state or migrate across states. Our focal estimates for the association between migration and employer and state characteristics are robust to the presence of within-state job changers, but the derivation and implementation of a rigorous estimation framework, which separates the causal effects of wage differentials on within-state job changes from the effects on migration flows, remains an interesting task for future econometric research.

Findings of our descriptive analysis are consistent with the idea that globalization acts on internal migration through employment benefits at foreign owned establishments, beyond spot wage differentials, and job stability at exporting establish- ments. Given annual formal sector migration rates of around $2 \%$, the magnitude of globalization predicted migration flows are potentially large. A $1 \%$ increase in exporter employment is associated with a $0.3 \%$ reduced probability of migration, and a $1 \%$ increase in the concentration of foreign owned establishments at potential migration destinations relates to approximately a $0.2 \%$ increase in the migration rate.

Recent research advances the hypothesis that return migration may be a leading cause of the large and unprecedented flows of people from Southern to Northern regions in Brazil (Fiess \& Verner, 2003 for a discussion and an opposing view based on evidence from a household cross-section). Our findings support the view that the now frequent relocation of foreign owned and exporting establishments to the Northern and Northeastern states may be one potential reason for return migration from the South and Southeast.

\section{NOTES}

1. At the core of the Harris and Todaro (1970) model is a pool of informal and unemployed workers in urban centers, to which rural migrants are attracted because there is a probability that they will be lifted out of informality into formal urban employment at a premium over the rural wage.

2. Au and Henderson (2006) argue that internal migration restrictions in China led to insufficient agglomeration of economic activity and resulted in significant productivity losses for the country.

3. The high average GDP per capita in the Center-West region is misleading, as the capital city in the Distrito Federal (DF) largely drives the results; the median per capita GDP for the region is only US\$ 5,925. Per capita GDP in the Distrito Federal is the highest in the country (US\$ $13,604)$, compared to only US\$ 4,403 in neighboring Goiás (GO) state.

4. Graham (1970), Martine (1990, chap. 2) and Schmertmann (1992) provide a detailed history of the Brazilian migration experience.

5. Our data do not include family variables like marital status or the number of children, however, which prior research has shown to be associated with migration. Inasmuch as family variables are related to prior workforce experience, we can control for their impact on migration selection because we observe workforce experience at the individual level.

6. Examples of such state promoted production arrangements include tropical horticulture in Amazonas (AM) state, furniture manufacturing in Acre (AC), software programming in the Distrito Federal, and apparel clusters in several states such as Goiás (GO), Rio Grande do Norte (RN), Paraíba (PB), and Sergipe (SE).

7. A worker's ID generally remains with the worker throughout his or her work history. The process for establishments to report on their workers is extensive and costly. However, RAIS records are used to administer payment of the annual public wage supplements to every formally employed worker, thus creating a strong incentive for workers to urge their employers to report accurately.

8. Educational attainment is defined as the level of schooling completed in nine categories.

9. Eleven digits is the traditional length of a PIS number in Brazil. Shorter PIS numbers are defective and not traceable over time. Firms that enter false identification numbers could be reporting informal workers, or have faulty bookkeeping.
10. We use the information for the years 1997-2001 when we also have complementary data.

11. Consider the following examples. An establishment with foreign investment inflows in 1997 and 1998 and a stock of foreign capital in 2001 is classified as a foreign owned establishment for the years 19972001. If an establishment with foreign inflows in 1997 and 1998 records no stock of foreign capital by 2001, the establishment is classified as foreign owned for 1997 and 1998 only. Finally, an establishment with a positive stock of foreign investment in 2001, but without any recorded inflows over the period 1996-2001, is classified as foreign owned for the years 1996-2001.

12. While it is possible to incorporate the level of exports, we opt to denote exporting establishments with a dummy indicator variable for consistency with the information on foreign owned enterprises. Moreover, without establishment information on production, it is unclear how we should scale exports.

13. Of the $1,005,010$ total worker-year observations, almost half $(161,540$ workers) can be traced for the entire sample period, while about a quarter (93,403 workers) can only be traced for two consecutive periods. Approximately $20 \%$ of workers are traced for three consecutive years (or two times two consecutive years) and approximately $12 \%$ of workers are traced for four consecutive years (or three times two consecutive years).

14. Death and retirement are reported in RAIS but account for only a minor fraction of workers who cannot be traced. The RAIS data do not allow us to decompose exits from the formal sector. Using household data, Menezes-Filho and Muendler (2007) estimate that just over two-thirds of workers with a job separation enter the informal sector or become selfemployed, while about one-third become unemployed or leave the labor force.

15. In order to ensure that the results that follow are not driven by these workers with multiple migration episodes, we repeat the analysis for a single 4-year (1997-2001) migration horizon (approximately 5\% of formal sector workers are employed in a different state in 2001 than the state of employment in 1997). Our main conclusions are unchanged when we exclude multiple migration episodes.

16. The fact that one-third of formal sector job switchers are cross-state migrants is of particular importance to the conduct of repeated household surveys, which invariably classify these households as missing and thus potentially exaggerate transitions into unemployment. 
17. Menezes-Filho and Muendler (2007) analyze this type of transition using household data.

18. Poole (2009) analyzes the impact of multinational-to-domestic worker mobility.

19. Approximately 2,000 workers migrate without changing jobsworkers who transfer within the firm or workers living in border areas.

20. We define a rich (poor) state to be a state with above (below) average per capita GDP for the sample period (see Table 1).

21. For a complete state-to-state transition matrix, please contact the authors.

22. Borjas (1987) posits a negative selection of cross-border migrants, whereas Chiquiar and Hanson (2005) document that Mexican immigrants to the United States are more educated than Mexican nonmigrants.

23. Women earn $41 \%$ less than men; wages are increasing in the level of education and increasing with age, at a decreasing rate.

24. This result, however, does not necessarily run contrary to commonly found regional migration patterns: states like Goiás often attract workers from states with higher per capita income, such as Minas Gerais and the capital city (Distrito Federal). Similarly, many migrants from São Paulo arrive in neighboring Paraná (PR) state, despite the lower per capita GDP.
25. Professional and managerial, technical, other white collar, skilled blue collar, and unskilled blue collar.

26. Child (10-14 yrs.), youth (15-17 yrs.), adolescent (18-24 yrs.), nascent career (25-29 yrs.), early career (30-39 yrs.), peak career (40-49 yrs.), late career (50-64 yrs.), and post-retirement (65+).

27. Primary school (grade 8 or less), high school graduate (grade 9-12), college dropout and college graduate.

28. In principle, migrants from 27 states to 26 states over four years in eight age groups, two gender groups and four education groups would make for 179,712 cells. But cells with no observations drop from the transformed sample (e.g., college educated, peak career, women from Tocantins in 1998).

29. A more rigorous treatment of immigration employer and immigration state predictors would require estimation of differences in emigration immigration characteristics similar to the two-step approach for spot wages. The derivation and implementation of an according statistical model remains a task for future research.

30. Women earn less than men; wages are increasing in the level of education and increasing with age, at a decreasing rate. Women are less likely to migrate than men, workers with at least some college are most likely to migrate, and the migration probability decreases with age. The higher are state average wages and value added in agriculture and manufacturing, the less likely is a worker to emigrate.

\section{REFERENCES}

Abowd, J. M., Kramarz, F., \& Margolis, D. N. (1999). High wage workers and high wage firms. Econometrica, 67(2), 251-333.

Amaral-Filho, J. (2001). A endogeneização no desenvolvimento econômico regional e local. Planejamento e Políticas Públicas, 23(7), 261-286.

Amaral-Filho, J. (2003). Ajustes estruturais, novas formas de intervenção pública e regime de crescimento econômico no Ceará. In M. F Gonçalves, C. A. Brandão, \& A. C. Galvão (Eds.), Regiões e Cidades, Cidades nas Regiões: O Desafio Urbano-Regional (pp. 367-385). São Paulo: UNESP.

Au, C.-C., \& Henderson, J. V. (2006). How migration restrictions limit agglomeration and productivity in China. Journal of Development Economics, 80(2), 350-388.

Bittencourt, M. V. L., Larson, D. W., \& Kraybill, D. L. (2008). A liberalização comercial e os seus impactos regionais sobre a pobreza e a distribuição de renda no Brasil. Pesquisa e Planejamento Econômico, $38(1), 127-166$

Borjas, G. J. (1987). Self-selection and the earnings of immigrants American Economic Review, 77(4), 531-553.

Chiquiar, D., \& Hanson, G. H. (2005). International migration, selfselection, and the distribution of wages: Evidence from Mexico and the United States. Journal of Political Economy, 113(2), 239-281.

Dahl, G. B. (2002). Mobility and the returns to education: Testing a Roy model with multiple markets. Econometrica, 70(6), 2367-2420.

Feenstra, R. C., Lipsey, R. E., Deng, H., Ma, A. C., \& Mo, H. (2005) World trade flows: 2005. NBER Working Paper 11040

Fiess, N. M., \& Verner, D. (2003). Migration and human capital in Brazil during the 1990s. World Bank Policy Research Working Paper 3093.

Graham, D. H. (1970). Divergent and convergent regional economic growth and internal migration in Brazil: 1940-1960. Economic Development and Cultural Change, 18(3), 362-382.

Harris, J., \& Todaro, M. (1970). Migration, unemployment, and development: A two-sector analysis. American Economic Review, 60, $126-142$.

Heckman, J. J. (1979). Sample selection bias as a specification error. Econometrica, 47(1)

Lastres, H. M. M., Cassiolato, J. E., \& Campos, R. (2006). Arranjos e sistemas produtivos e inovativos locais: Vantagens e enfoque. In H. M.
M. Lastres, \& J. E. Cassiolato (Eds.). Estratégias para o Desenvolvimento: Um Enfoque sobre Arranjos Produtivos Locais do Norte, Nordeste e Centro-Oeste Brasileiro (pp. 13-28). Rio de Janeiro: Instituto de Economia da Universidade Federal do Rio de Janeiro.

Martine, G. (1990). Brazil. In C. B. Nam, W. J. Serow, \& D. F. Sly (Eds.). International Handbook of Internal Migration (pp. 31-46). New York: Greenwood Press.

Meier, G. M., \& Rauch, J. E. (2005). Leading issues in economic development. New York: Oxford University Press.

Menezes-Filho, N. A., \& Muendler, M.-A. (2007). Labor reallocation in response to trade reform. CESifo Working Paper 1936.

Menezes-Filho, N. A., Muendler, M.-A., \& Ramey, G. (2008). The structure of worker compensation in Brazil, with a comparison to France and the United States. Review of Economics and Statistics, 90(2), 324-346.

Mincer, J. (1974). Schooling, experience, and earnings. New York: Columbia University Press.

Poole, J. P. (2009). Knowledge transfers from multinational to domestic firms: Evidence from worker mobility. University of California Santa Cruz, Unpublished manuscript.

Roy, A. D. (1951). Some thoughts on the distribution of earnings. Oxford Economic Papers, 3, 135-146.

Sahota, G. S. (1968). An economic analysis of internal migration in Brazil. Journal of Political Economy, 76(2), 218-245.

Schmertmann, C. P. (1992). Estimation of historical migration rates from a single census: Interregional migration in Brazil 1900-1980. Population Studies, 46(1), 103-120.

Yap, L. (1976). Internal migration and economic development in Brazil. Quarterly Journal of Economics, 90(1), 119-137.

\section{APPENDIX A}

See Table A.1. 
Table A.1. Selectivity corrected wage estimation for workers with a job change.

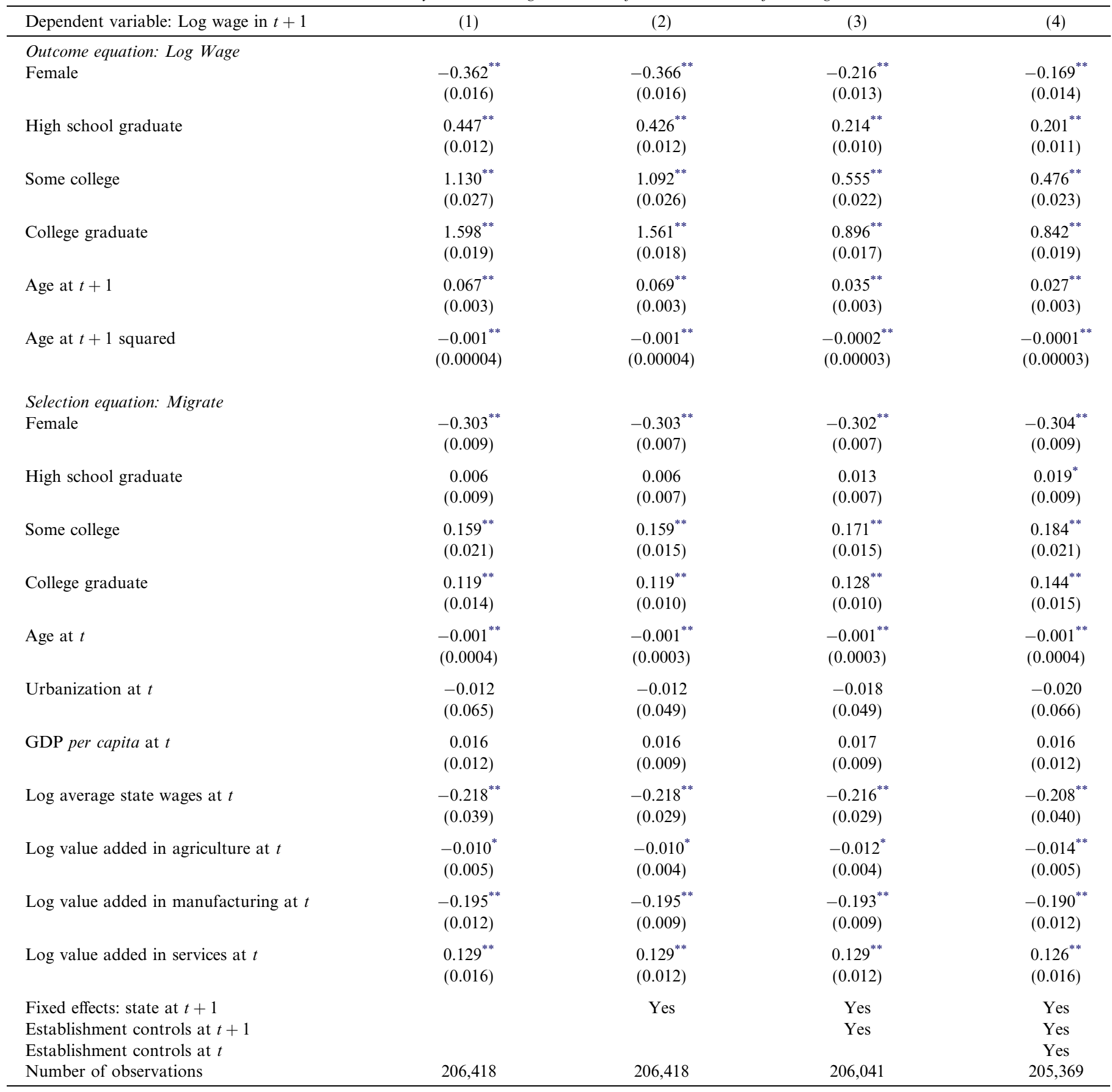

Notes: The sample is restricted to workers with a year-to-year job change. Establishment controls include average wages, number of workers, the share of female workers, and the share of workers in eight age groups, four education groups, and five occupational groups. Robust standard errors are in parentheses.

Sources: RAIS (1\% random sample) and IBGE (1997-2001).

* Significance at the $5 \%$ level.

${ }^{* *}$ Significance at the $1 \%$ level. 